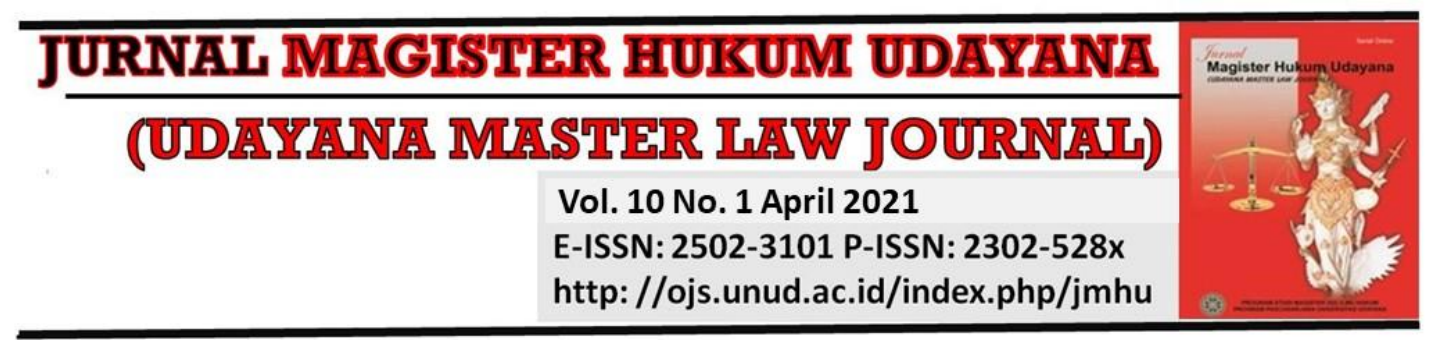

\title{
Persoalan Dilematis Lembaga Perwakilan Daerah dalam Sistem Ketatanegaraan Indonesia
}

\author{
Hezron Sabar Rotua Tinambunan', Bagus Oktafian Abrianto² \\ ${ }^{1}$ Fakultas Ilmu Sosial dan Hukum Universitas Negeri Surabaya, \\ E-mail: hezrontinambunan@unesa.ac.id \\ 2Fakultas Hukum Universitas Airlangga, E-mail: bagusoa@fh.unair.ac.id
}

\begin{tabular}{l}
\hline Info Artikel \\
\hline Masuk: 23 September 2020 \\
Diterima: 4 April 2021 \\
Terbit: 9 April 2021 \\
Keywords: \\
DPD; Balance; Authority; \\
Amandments \\
\\
Kata kunci: \\
DPD; Keseimbangan; \\
Kewenangan; Amandemen \\
Corresponding Author: \\
Hezron Sabar Rotua \\
Tinambunan, Email: \\
hezrontinambunan@unesa.ac.id \\
DoI: \\
10.24843/JMHU.2021.v10.i01.p \\
06
\end{tabular}

\begin{abstract}
The purpose of this research is to study and analyze the Dilemma Problems of Regional Representative Institutions in the Indonesian State Administration System, in this case the DPD which is a State institution in the category of state institutions using normative juridical categories through licensing in accordance with the demand (statute approach) and conceptual (approach conceptual), thus the DPD obligation related to the implementation of regional autonomy which is limited to providing an assessment also shows the weakness of the DPD's function because it cannot fight for regional interests in increasing the DPD's consideration which is not followed up by the DPR

Abstrak
Tujuan dari penelitian ini adalah untuk meninjau dan
menganalisis Persoalan Dilematis Lembaga Perwakilan Daerah
Dalam Sistem Ketatanegaraan Indonesia dalam hal ini DPD
yang merupakan lembaga Negara yang masuk kategori main
state organ dengan menggunakan metode yuridis normatif
melalui pendekatan perundang-undangan (statute approach) dan
pendekatan konseptual (conseptual approch), bahwa Kewenangan
DPD berkaitan dengan penyelenggaraan otonomi daerah yang
sebatas memberikan pertimbangan pun menampakkan
kelemahan fungsi DPD karena tidak dapat memperjuangkan
kepentingan daerah terhadap kemungkinan pertimbangan DPD
yang tidak ditindaklanjuti oleh DPR
\end{abstract}

\section{Pendahuluan}

Negara Indonesia yang dicita-citakan oleh the founding father adalah Negara hukum bukan Negara yang didasarkan atas kekuasaaan belaka. Pasal 1 ayat (3) perubahan keempat Undang-Undang Dasar Negara Republik Indonesia Tahun 1945 (selanjutnya disebut UUD NRI 1945) yang menyatakan bahwa Negara Indonesia adalah negara Hukum. Ide dasar Negara hukum Indonesia tidak dilepaskan dari ide dasar tentang Negara hukum yang meletakan dasar perlindungan hukum pada asas legalitas. ${ }^{1}$

\footnotetext{
1 Rosyid Al Atok, "CHECKS AND BALANCES DALAM PEMBENTUKAN UNDANGUNDANG DENGAN SISTEM BIKAMERAL DI 5 (LIMA) NEGARA KESATUAN," Jurnal Legislasi Indonesia 13a, no. 3 (2018): 261-72.
} 
Dalam tradisi hukum di Negara-negara yang menganut sistem hukum civil law, seperti Indonesia keberadaan pemisahan kekuasaan sebagai salah satu bentuk implementasi dari prinsip negara hukum adalah suatu keniscayaan. Penerapan konsep pemisahan kekuasaan dan pembagian kekuasaan di zaman modern sudah saling kombinasi antara konsep pemisahan kekuasaan dengan konsep checks and balances, sehingga konsep hybrid seperti ini disebut dengan istilah (distribution of power). ${ }^{2}$ Dalam hal ini kekuasaan tidak dipisah secara tegas tetapi hanya dibagi-bagi, sehingga memungkinkan timbulnya overlapping kekuasaan. Meskipun begitu, konsep awal dari ajaran trias politica yang berasal dari Montequieu, yang bermaksud untuk memisahkan sama sekali di antara kekuasaan-kekuasaan tersebut, yakni kekuasaan legislatif, eksekutif dan yudikatif. Konsep ini dalam sejarah ketatanegaraan dulu dianut oleh Eropa Kontinental. Sedangkan Konsep Checks and balances ${ }^{3}$ berasal dari para The Founding Fathers Amerika Serikat, yang memisakan secara tegas satu sama lain namun saling mengawasi tanpa adanya satu kekuasaan yang berada di atas atau (tidak menjadi master atau kekuasaan yang lain) masing-masing mengawasi mekanisme check and balances berjalan dengan baik, disamping juga terhindar dari kesewenangwenangan. ${ }^{4}$

Setelah Undang-Undang Dasar Negara Republik Indonesia Tahun 1945 (UUD NRI 1945) pasca amendemen, kedaulatan rakyat ditentukan dibagikan secara horizontal dengan cara memisahkannya (separation of power) menjadi kekuasaan yang dinisbatkan/ atau dilaksanakan sebagai fungsi lembaga-lembaga negara yang kedudukannya sederajat dan saling mengendalikan satu sama lain berdasarkan prinsip checks and balances yang merujuk pada konsep trias politika. Cabang kekuasaan legislatif tetap berada pada MPR, namun Majelis ini terdiri dari dua badan perwakilan yang sederajat dengan lembaga negara lainnya. Untuk melengkapi pelaksanaan tugas pengawasan, disamping lembaga legislatif dibentuk pula Badan Pemeriksa keuangan. Cabang kekuasaan Eksekutif berada ditangan Presiden dan Wakil Presiden. Adapun cabang kekuasaan kehakiman atau yudikatif dipegang oleh dua jenis Mahkamah, yaitu, Mahkamah Agung dan Mahkamah Konstitusi. Prinsip perwakilan daerah dalam Dewan perwakilan Daerah (selanjutnya disebut DPD) menurut Jilmly, harus dibedakan hakikatnya dari prinsip perwakilan rakyat dalam Dewan Perwakilan Rakyat (selanjutnya disebut DPR). Jimly, bermaksud bahwa agar seluruh aspirasi rakyat benar-benar dapat dijelmakan kedalam Majelis Permusyawaratan Rakyat (selanjutnya disebut MPR) yang berdiri sendiri, disamping terdiri atas kedua lembaga perwakilan itu menyebabkan struktur parlemen Indonesia, terdiri dari tiga pilar, yaitu, MPR, DPR dan DPD digambarkan dengan trikameral. Tiga badan tersebut mempunyai kedudukan yang sederajat dengan Presiden dan pelaksanaan kekuasaan Kehakiman yang terdiri atas Mahkamah Agung dan Mahkamah Konstitusi.

2 Fauziyah Fauziyah and I Wayan Parsa, "The Concept of Special Judicial Institutions in Dispute Resolution of Village Heads In Indonesia," Jurnal Magister Hukum Udayana (Udayana Master Law Journal) 9, no. 4 (2020): 673-83.

${ }^{3}$ Zulkarnain Ridlwan and Ade Arif Firmansyah, "Law Enforcement and Justice: Perspective of Authority and Responsibility of the President towards the Judicial System," Jurnal Magister Hukum Udayana (Udayaana Master Law Journal) 9, no. 1 (2020): 1-14.

${ }^{4}$ I Gusti Ngurah Adityanatha, "Kajian Yuridis Hak Angket Dewan Perwakilan Rakyat Terhadap Komisi Pemberantasan Korupsi (Dikaji Dari Perspektif Hukum Tata Negara)," Acta Comitas: Jurnal Hukum Kenotariatan 4, no. 1 (2019): 142-53. 
Dewan Perwakilan Daerah adalah lembaga negara baru dalam struktur ketatanegaraan Indonesia bila dibandingkan dengan lembaga yang lain seperti DPR dan MPR, yang merupakan hasil dari amandemen Undang-Undang Dasar 1945. Keberadaan Dewan Perwakilan Daerah, dianggap sebagai perwujudan dari sistem perwakilan dengan struktur dua kamar atau bikameral di dalam sistem pemerintahan Presidensiil. Oleh karena itu seharusnya Dewan Perwakilan Daerah juga diberikan kekuasaan legislatif agar dapat mengimbangi dan mengawasi Dewan Perwakilan Rakyat berdasarkan prinsip checks and balance. ${ }^{5}$ Selain itu, tujuan dibentuknya Dewan Perwakilan Daerah adalah untuk memperkuat peran daerah dalam proses penyelenggaraan negara yang merupakan salah satu elemen penting dalam pemeliharaan Negara Kesatuan Republik Indonesia. ${ }^{6}$

Menurut pendapat Ramlan Surbakti, beberapa pertimbangan Indonesia membentuk Dewan Perwakilan Daerah yaitu: Pertama, distribusi penduduk Indonesia menurut wilayah sangat timpang dan terlampau besar terkonsentrasi di Pulau Jawa, Kedua, sejarah Indonesia menunjukkan aspirasi kedaerahan yang sangat nyata dan mempunyai basis materiil yang sangat kuat, yaitu adanya pluralisme daerah otonom seperti daerah istimewa daerah khusus. ${ }^{7}$

Anggota DPD dipilih secara langsung melalui pemilu. DPD memiliki wewenang untuk membahas RUU yang berkaitan dengan otonomi daerah, hubungan pusat dan daerah, dan RUU lain yang mempunyai keterkaitan dengan daerah. RUU tersebut diajukan kepada DPR. Dan setelah itu, barulah dibahas bersama-sama oleh DPD dan DPR. DPD sejatinya adalah salah satu lembaga perwakilan yang berisi orang-orang pilihan rakyat. Namun kekuasaan DPD jika dibandingkan dengan DPR, sangatlah kecil. Ketidakberimbangan kekuasaan antar lembaga perwakilan ini mengakibatkan terjadinya kekuasaan yang sangat besar yang dimiliki oleh DPR. Tentunya hal ini harus dihindari karena kita pada prinsipnya menganut sistem bikameral. Perlu dipikirkan kembali sebagai salah satu bentuk evaluasi terhadap Amandemen UUD 1945. Oleh karena itu Penelitian ini terfokus pada Persoalan Dilematis Lembaga Perwakilan Daerah Dalam Sistem Ketatanegaraan Indonesia dalam hal ini DPD yang merupakan lembaga Negara yang masuk kategori main state organ yang kewenangannya diberikan secara langsung melalui UUD NRI 1945 namun adanya Ketidakberimbangan terkait konsep kekuasaan antar lembaga perwakilan Sebagai pembanding dan pembeda penulisan ini dengan penulisan lain yang relevan penulis menunjukkan beberapa yakni Hernadi Affandi memaparkan upaya yang harus dilakukan untuk memperkuat fungsi legislatif DPD, selain itu dari Ni'matul Huda mengkaji terkait urgensi amandemen ulang Konstitusi 1945 adalah untuk meningkatkan hasil amandemen sebelumnya, yaitu untuk memberikan pemerintahan pemerintahan yang lebih baik di Indonesia. Tidak perlu dikatakan bahwa konstitusi 1945 adalah suci, sebagaimana amandemen juga dapat tidak dianggap sembarangan. ${ }^{8}$

${ }^{5}$ Pataniari Siahaan, Politik Hukum Pembentukan Undang-Undang Pasca Amandemen UUD 1945 (Konstitusi Press, 2012).

${ }^{6}$ Lenny M L Sipangkar and Hak Asasi Manusia Sumatera Utara, "Penguatan Fungsi Legislasi Dewan Perwakilan Daerah (Strengthening The Legislative Function Of Regional Refresentative Council)," Dari Redaksi, 2018, 235.

7 Titik Triwulan Tutik and M H SH, Konstruksi Hukum Tata Negara Indonesia Pasca Amandemen UUD 1945 (Prenada Media, 2016).

8 Ni'matul Huda, "Gagasan Amandemen (Ulang) UUD 1945 (Usulan Untuk Penguatan DPD Dan Kekuasaan Kehakiman)," Jurnal Hukum IUS QUIA IUSTUM 15, no. 3 (2008): 373-92. 
Selain itu, Titik Triwulan Tutik ${ }^{9}$ mengkaji terkait menguji fungsi harmonisasi antara DPD dan DPR dalam perwakilan lembaga dalam sistem bikameral.

Dengan adanya reformasi pada tahun 1998 yang dipelopori oleh mahasiswa, telah berhasil merubah Undang-Undang Dasar Negara Republik Indonesia Tahun 1945 dan penyempurnaanya demi menjamin kedaulatan yang lebih modern. Karena adanya tuntutan demokrasi una memenuhi rasa keadilan masyarakat di daerah serta meningkatkan semangat dan kapasitas partisipasi daerah dalam kehidupan nasional, maka dalam rangka pembaharuan konstitusi, Majelis Permusyawaratan Rakyat (MPR) membentuk sebuah lembaga perwakilan baru, yakni Dewan Perwakilan Daerah (DPD). Pembentukan DPD ini dilakukan melalui perubahan ketiga UUD 1945 pada bulan November 2001. DPD adalah sebuah lembaga perwakilan seperti halnya Dewan Perwakilan Rakyat (DPR) yang mewakili masyarakat pada wilayah tertentu.. DPD merupakan alternatif baru bagi bentuk "utusan daerah" di MPR, yang lebih merepresentasikan kepentingan daerah. Bila pada MPR sistem yang lama anggota utusan daerah merupakan hasil pemilihan eksklusif anggota DPRD Provinsi, maka anggota DPD dipilih melalui Pemilihan umum (pemilu) melalui sistem distrik berwakil banyak. Dalam sisitem ini, masyarakat langsung memilih nama kandidat, yang memang disyaratkan untuk independen (bukan pengurus Partai Politik).

\section{Metode Penelitian}

Tipe penelitian yang digunakan adalah penelitian hukum normatif dengan beberapa pendekatan penelitian meliputi pendekatan Perundang-undangan dan pendekatan konseptual. ${ }^{10}$ Secara umum, penelitian hukum normatif sering diistilahkan dengan penelitian kepustakaan (library research) ${ }^{11}$, hal ini dikarenakan kecenderungan penelitian hukum normatif yang menggunakan dokumen-dokumen sebagai bahan penelitiannya. Penelitian hukum normative juga diartikan sebagai penelitian terhadap asas-asas hukum, sistematika hukum, taraf sinkronisasi hukum, sejarah hukum sampai dengan perbandingan hukum.12 Bahan hukum yang digunakan adalah bahan hukum primer yang digunakan dalam penelitian ini diantaranya: UUD NRI 1945 dan peraturan perundang-undangan yang terkait. Bahan hukum sekunder yang memiliki kaitan dengan bahan hukum primer untuk membantu menganalisis bahan hukum primer seperti jurnal ilmiah, buku-buku yang ditulis oleh para ahli hukum, serta naskah-naskah penelitian lain yang sejenis. Sedangkan bahan non hukum yang membantu menjelaskan bahan hukum primer dan bahan hukum sekunder seperti kamus, ensiklopedia dan lain sebagainya. Adapun teknik pengumpulan bahan hukum yang digunakan menggunakan studi kepustakaan. Dari bahan hukum yang terkumpul kemudian dianalisis secara kualitatif-normatif dengan jalan menafsirkan dan mengkontruksikan pernyataan yang terdapat dalam dokumen dan perundangundangan serta menggunakan pendekatan perundang-undangan (statute approach) dan pendekatan konseptual (conseptual approch).

${ }^{9}$ Titik Triwulan Tutik, "Harmonisasi Fungsi DPD Dan DPR Pada Lembaga Perwakilan Rakyat Dalam Sistem Bikameral Guna Pelaksanaan Checks and Balances," Yustisia Jurnal Hukum 1, no. 3 (2012).

${ }^{10}$ Depri Liber Sonata, "Metode Penelitian Hukum Normatif Dan Empiris: Karakteristik Khas

Dari Metode Meneliti Hukum," Fiat Justisia Jurnal Ilmu Hukum 8, no. 1 (2014): 15-35.

11 Ibid.

12 Bambang Sunggono, Metodologi Penelitian Hukum (PT. Rajagrafindo Persada, 2011). h. 41-41. 


\section{Hasil dan Pembahasan}

UUD 1945 setelah amandemen menghasilkan sistem bikameral dalam kekuasaan legislatif, yaitu selain adanya DPR dibentuk pula DPD sebagi lembaga perwakilan, yang anggotanya dipilih dari setiap provinsi secara langsung. Jumlah anggota DPD tidak lebih dari sepertiga dari anggota DPR. Keberadaan DPD sebagai lembaga perwakilan daerah menjadi penting untuk mewakili aspirasi masyarakat daerah. Namun, sayang kewenangan yang dimiliki DPD terdapat ketidakberimbangan jika melihat kewenangan yang dimiliki oleh DPR. Dengan kondisi seperti itu maka sistem bikameral yang dianut cenderung soft bicameral. Hal ini karena DPD tidak memiliki kewenangan yang sama seperti DPR, baik dalam fungsi legislasi, pengawasan maupun anggaran. Berikut tabel fungsi, tugas dan kewenangan Dewan Perwakilan Daerah:

Tabel 1. Tabel fungsi, tugas dan kewenangan Dewan Perwakilan Daerah

\begin{tabular}{|c|c|c|c|c|}
\hline \multicolumn{5}{|c|}{ Kewenangan DPD } \\
\hline $\begin{array}{l}\text { RUU yang } \\
\text { berkaitan }\end{array}$ & $\begin{array}{c}\text { Dapat } \\
\text { mengajukan }\end{array}$ & Ikut membahas & $\begin{array}{c}\text { Materi } \\
\text { Pertimbangan }\end{array}$ & $\begin{array}{c}\text { Dapat } \\
\text { Melakukan } \\
\text { Pengawasan }\end{array}$ \\
\hline $\begin{array}{l}\text { Otonomi } \\
\text { Daerah }\end{array}$ & $\sqrt{ }$ & $\sqrt{ }$ & & $\sqrt{ }$ \\
\hline $\begin{array}{ll}\text { Hubungan } & \\
\text { Pusat dan } \\
\text { Daeah }\end{array}$ & $\sqrt{ }$ & $\sqrt{ }$ & & $\sqrt{ }$ \\
\hline $\begin{array}{l}\text { Pembentukan } \\
\text { dan pemekaran } \\
\text { serta } \\
\text { penggabungan } \\
\text { daerah }\end{array}$ & $\sqrt{ }$ & $\sqrt{ }$ & & $\sqrt{ }$ \\
\hline \begin{tabular}{l}
\multicolumn{2}{l}{ Pengelolaan } \\
SDA dan \\
Sumber daya \\
ekonomi \\
lainnya
\end{tabular} & $\sqrt{ }$ & $\sqrt{ }$ & & $\sqrt{ }$ \\
\hline $\begin{array}{l}\text { Perimbangan } \\
\text { keuangan pusat } \\
\text { dan daerah }\end{array}$ & $\sqrt{ }$ & $\sqrt{ }$ & & $\sqrt{ }$ \\
\hline RAPBN & & & $\sqrt{ }$ & $\sqrt{ }$ \\
\hline Pajak & & & $\sqrt{ }$ & $\sqrt{ }$ \\
\hline Pendidikan & & & $\sqrt{ }$ & $\sqrt{ }$ \\
\hline Agama & & & $\sqrt{ }$ & $\sqrt{ }$ \\
\hline
\end{tabular}

Rumusan Pasal 5 ayat (1) dan Pasal 20 ayat (1) mengalami perubahan besar yang mengakibatkan penempatan DPR sebagai lembaga utama pemegang kekuasaan pembuat Undang-undang. Kekuasaan DPR lainnya pada proses legislasi diperkuat oleh Pasal 20 ayat (5) UUD 1945. Kewenangan DPR terkait fungsi legislasi tercantum dalam Pasal 20 ayat (1) sampai dengan ayat (3) UUD 1945 yaitu:

(1) Dewan Perwakilan Rakyat memegang kekuasaan membentuk undangundang

(2) Setiap rancangan undang-undang dibahas oleh Dewan Perwakilan Rakyat dan Presiden untuk mendapat persetujuan bersama 
(3) Jika rancangan undang-undang itu tidak mendapat persetujuan bersama, rancangan undang-undang itu tidak boleh diajukan lagi dalam persidangan Dewan Perwakilan Rakyat masa itu.

Berdasarkan hal tersebut, DPR sebagai lembaga perwakilan berdasarkan aspirasi dan paham politik rakyat sebagai pemegang kedaulatan, sedangkan DPD merupakan lembaga perwakilan penyalur keanekaragaman aspirasi daerah. Adanya lembaga negara DPD merupakan upaya mewadahi aspirasi daerah untuk memperkuat konsep perwakilan daerah dan untuk melaksanakan prinsip checks and balances antar lembaga perwakilan. Hal ini dapat dilihat secara eksplisit melalui Pasal 2 ayat (1) UUD NRI 1945 yang Menyatakan bahwa "Majelis Permusyawaratan Rakyat terdiri atas anggota Dewan Perwakilan Rakyat dan anggota Dewan Perwakilan Daerah".

Dalam sistem ketatanegaraan Indonesia saat ini, kehadiran DPD sebagai upaya memperkuat konsep perwakilan namun dalam fakta yuridis, DPD tidak memiliki kedudukan yang jelas. Apalagi pengaturan dalam UUD 1945 yang berkaitan dengan DPD tidak diatur secara komprehensif dan sangat sumir yang mengakibatkan adanya intepretasi bahwa kehadiran DPD sebuah keniscayaan. Hal ini dapat dilihat sebagaimana tertuang dalam Pasal 22C, Pasal 22D, Pasal 23E ayat (1), dan Pasal 22F ayat (2), DPD sama sekali tidak memiliki kekuasaan apapun, selain hanya memberikan pertimbangan, usul, ataupun saran kepada DPR sebagai lembaga yang memutuskan, baik dalam bidang legislatif maupun pengawasan. Kewenangan DPD berkaitan dengan penyelenggaraan otonomi daerah yang sebatas memberikan pertimbangan pun menampakkan kelemahan fungsi DPD karena tidak dapat memperjuangkan kepentingan daerah terhadap kemungkinan pertimbangan usul, ataupun saran DPD yang tidak ditindaklanjuti oleh DPR. Apalagi rancangan undang-undang yang tidak sesuai dengan kepentingan daerah tidak dapat dibatalkan oleh DPD dengan menggunakan hak yang dimiliki DPD, sebagaimana dipraktikkan dalam sistem perwakilan bikameral. Hal inilah yang mengakibatkan DPD tidak memiliki kekuasaan sama sekali dalam sistem ketatanegaraan saat ini yang membuat kedudukan DPD sangat dilematis. DPD yang lahir sebagai kamar kedua di parlemen yang mengemban amanat perwakilan daerah lahir dengan kewenangan yang sangat lemah dari konstitusi. Keadaan yang lemah ini menjadi salah satu penghambat secara struktural bagi DPD untuk menjalankan mandat perwakilan yang dimilikinya. Salah satu tugas DPD misalkan terkait menyerap hasil aspirasi dari daerah akan tetapi hal itu hanya mampu sampai ada proses komunikasi dengan pemerintah dengan DPR yang mana hasil akhir dari aspirasi tersebut kembali ditangan Pemerintah dan DPR. Sedangkan di fungsi legislasi DPD tidak memilki hak untuk ikut membahas sampai akhir serta hak untuk ikut serta dalam pengambilan keputusan. Hal tersebut berdampak meskipun secara produktivitas DPD mampu melahirkan cukup banyak RUU akan tetapi RUU tersebut tidak mampu diundangkan. Keikutsertaan DPD dalam pembahasan RUU bidang tertentu, yang mana DPD tidak diberikan ruang artikulasi lebih dalam pembahasan Daftar Inventarisasi Masalah (DIM) sebagai instrumen pembahasan RUU di DPR. Jadi dengan fungsi yang ada saat ini DPD tidak lebih hanya sekadar sebagai lembaga perwakilan yang lemah kedudukannya dalam pembahasan RUU.

\subsection{Kedudukan Dewan Perwakilan Daerah pasca Amandemen}


Pembentukan DPD sebagai salah satu institusi negara yang baru bertujuan memberikan kepada orang-orang daerah untuk ikut mengambil kebijakan dalam tingkat nasional, khususnya yang terkait kepentingan daerah. ${ }^{13}$ Berdasarkan Ketentuan Pasal 22D ayat (1) dan ayat (2) UUD NRI 1945, DPD memiliki kewenangan dalam hal pembuatan Undang-Undang dan Pembahasan Rancangan Undang-Undang, walaupun terdapat pembahasan Rancangan Undang-Undang. Keberadaan DPD dalam sistem ketatanegaraan. Indonesia tidak dapat dilepaskan dari pelembagaan fungsi representasi. Dalam Rangka pelembagaan fungsi representasi itu dikenal adanya 3 (tiga) sistem perwakilan yang dipraktikkan di berbagai negara demokrasi yaitu: ${ }^{14}$

a. Sistem perwakilan politik (political representative)

b. Sistem perwakilan teritorial (teritorial representative); dan

c. Sistem perwakilan fungsional (fungsional representative)

Undang-Undang Nomor 17 Tahun 2014 tentang Majelis Permusyawaratan Rakyat, Dewan Perwakilan Rakyat, Dewan Perwakilan Daerah, dan Dewan Perwakilan Rakyat Daerah sebagaimana telah diubah menjadi Undang-Undang Nomor 42 Tahun 2014 tentang Perubahan atas Undang-Undang Nomor 17 tahun 2014 Tentang Majelis Permusyawaratan Rakyat, Dewan Perwakilan Rakyat, Dewan Perwakilan Daerah, Dan Dewan Perwakilan Rakyat Daerah dan Undang-Undang Nomor 12 tahun 2011 Tentang Pembentukan Peraturan Perundang-Undangan (UU P3).

DPD dalam rangka kurun waktu Oktober 2004 sampai dengan Oktober 2014 telah mengajukan 57 (lima puluh tujuh) RUU, 237 (dua ratus tiga puluh tujuh) pandangan dan pendapat, 74 (tujuh puluh empat) pertimbangan dan 138 (seratus tiga puluh delapan) hasil pengawasan. Seluruh RUU telah disampaikan Kepada DPR namun tidak semua ada tindak lanjutnya. Beberapa RUU usul inisiatif DPD dan keterlibatan DPD dalam pembahasan RUU tersebut sangat terbatas, hanya RUU kelautan yang menjadi usul inisiatif DPD dan akhirnya menjadi Undang-Undang yang pembahasannya dilakukan secara 3 (tiga) pihak (tripatri) yaitu: DPR, pemerintah dan DPD. 15

Yang menarik dan patut dicermati dari lembaga tinggi di Indonesia ini adalah Dewan Perwakilan Daerah yang sejatinya merupakan majelis tinggi yang memiliki kewenangan sama dengan DPR, akan tetapi dalam kenyataannya Dewan Perwakilan Daerah hanya dapat dikatakan sebagai badan komplementer DPR saja. Sebagai salah satu contoh adanya kepentingan antar keduanya ialah kewenangan DPD dengan DPR dapat dilihat dalam Undang-Undang Nomor 42 Tahun 2014 tentang perubahan atas undang-undang nomor 17 tahun 2014 Tentang Majelis Permusyawaratan Rakyat, Dewan Perwakilan Rakyat, Dewan Perwakilan Daerah. Pada Undang-Undang tersebut, DPR diberikan kewenangan untuk dapat memutuskan perundanganundangan melalui persetujuan bersama dengan presiden. Sedangkan pada Dewan Perwakilan Daerah tidak terdapat pada UUD 1945 mengenai kewenangan DPD RI untuk dapat memutuskan perundang-undangan seperti halnya DPR RI melainkan hanya fungsi legislasi DPD yang sekedar memberi pertimbangan saja.

${ }^{13}$ Firmansyah Arifin, "Lembaga Negara Dan Sengketa Kewenangan Antarlembaga Negara," Jakarta: Konsorsium Reformasi Hukum Nasional, 2005.

14 Jimly Asshiddiqie, "Pengantar Ilmu Hukum Tata Negara Jilid II," 2006.

${ }^{15}$ Sekretariat Jenderal DPD RI, Profil Dewan Perwakilan Daerah Republik Indonesia Tahun Sidang 2014- 2015 (Jakarta: Sekretariat Jenderal DPD RI, 2015). 
Kewenangan DPD berdasarkan landasan konstitusionalnya yang kemudian direduksi oleh Undang-Undang MPR, DPR, DPD, dan DPRD (UU MD3) telah memberikan kerugian konstitusional terhadap DPD. Terdapat beberapa pasal yang telah mengurangi fungsi, tugas kewenangan DPD dari kehendak konstitusi. Kondisi ini dianggap tidak memberikan sistem yang baik mengingat legitimasi anggota DPD yang sangat kuat dan kelembagaan DPD sebagai lembaga tinggi negara, seharusnya dapat bekerja dengan kewenangan signifikan sebagai teritorial representation.

DPD sebagai lembaga perwakilan yang menggantikan utusan daerah dan golongan di MPR melalui amandemen ke tiga (2001) yang kemudian disempurnakan dalam amandemen ke empat (2002) UUD 1945. Pembentukan DPD tidak lepas dari 2 (dua) hal yaitu: Pertama, adanya tuntutan demokratisasi pengisian anggota lembaga agar selalu mengikutsertakan rakyat pemilih. Keberadaan utusan daerah dan utusan golongan dalam komposisi MPR digantikan dengan keberadaan DPD. Kedua, karena adanya tuntutan penyelenggaraan otonomi daerah yang jika tidak dikendalikan dengan baik akan berujung pada tuntutan sparatisme. DPD dibentuk sebagai representasi kepentingan rakyat di daerah. Utusan golongan sendiri kemudian dihapus karena penentuan utusan golongan dianggap menyulitkan demokrasi serta utusan golongan dianggap sudah dapat disalurkan dan diwadahi melalui keberadaan dari DPD.

Sebelumnya, jumlah Utusan daerah dan golongan di MPR adalah lebih dari setengah anggota MPR, dan kemudian menjadi sepertiga anggota MPR. Sedangkan kewenangannya sebagai anggota MPR yang meliputi:

1. Menetapkan Undang-Undang Dasar 1945 (Pasal 3 UUD 1945),

2. Menetapkan Garis-Garis Besar Halauan Negara (Pasal 3 UUD 1945),

3. Memilih presiden dan wakil presiden (Pasal 6 UUD 1945) dan,

4. Mengangkat presiden dan wakil presiden (Pasal 9 UUD 1945).

Sistem rekruitmen yang digunakan untuk mengisi kursi utusan daerah di MPR adalah melalui pemilihan yang dilakukan oleh anggota DPRD tingkat satu. Sedangkan untuk utusan golongan dipilih oleh presiden dengan penetapan golongannya ditetapkan oleh DPR. Dengan demikian diharapkan mampu menghasilkan wakil yang mampu mengejawantahkan suara rakyat dalam bentuk perwakilan yang utuh yaitu memahami aspirasi, nilai, kepercayaan dan sikap dari golongan dan daerah yang diwakili. Dengan berubahnya utusan daerah dan golongan melalui amandemen ketiga dan keempat juga telah mengubah perwakilan fungsional. Sebagai pengganti dari utusan daerah dan golongan, DPD mempunyai banyak perbedaan dengan utusan daerah dan golongan.

Pasca reformasi lahirnya lembaga baru yang bernama Dewan Perwakilan Daerah, maka terjadi perubahan dalam konstitusi Republik Indonesia yaitu dengan amandemen UUD 1945. Dalam Pasal 22 setelah amandemen pengaturan kedudukan, fungsi, tugas dan kewenangan Dewan Perwakilan Daerah mulai muncul yaitu dalam Pasal 22D UUD 1945 dimana Dewan Perwakilan Daerah mempunyai fungsi, tugas dan kewenangan dalam bidang legislasi, namun fungsi legislasi dari Dewan Perwakilan Daerah sangatlah terbatas hanya yang berkaitan dengan daerah. Keberadaan DPD dalam sistem ketatanegaraan Indonesia merupakan salah satu upaya mewujudkan sistem bikameral demi terlaksananya prinsip checks and balances. Namun dalam implementasinya, DPD mempunyai wewenang yang sangat terbatas dan hanya terkait 
dengan soal-soal kedaerahan. Dalam Pasal 22D UUD NRI 1945 sangatlah jelas kewenangan DPD yaitu:

(1) Dewan Perwakilan Daerah dapat mengajukan kepada Dewan Perwakilan Rakyat rancangan undang-undang yang berkaitan dengan otonomi daerah, hubungan pusat dan daerah, pembentukan dan pemekaran serta penggabungan daerah, pengelolaan sumber daya alam dan sumber daya ekonomi lainnya, serta yang berkaitan dengan perimbangan keuangan pusat dan daerah

(2) Dewan Perwakilan Daerah ikut membahas rancangan undang-undang yang berkaitan dengan otonomi daerah; hubungan pusat dan daerah; pembentukan, pemekaran dan penggabungan daerah, pengelolaan sumber daya alam dan sumber daya ekonomi lainnya, serta perimbangan keuangan pusat dan daerah; serta memberikan pertimbangan kepada Dewan Perwakilan Rakyat atas rancangan undangundang anggaran pendapatan dan belanja Negara dan rancangan undang-undang yang berkaitan dengan pajak, pendidikan dan agama.

Dalam Pasal 22D ayat (1) dan (2) dapat diartikan bahwa DPD hanya "dapat" mengajukan RUU, "ikut membahas" RUU dan "dapat" melakukan pengawasan atas pelaksanaan undang-undang, dengan catatan bahwa kewenangan tersebut hanya terbatas pada undang-undang yang berkaitan dengan otonomi daerah Namun wewenang DPD yang diberikan oleh UUD NRI 1945 dilakukan sebelum pembahasan oleh DPR. Dalam hal terbetuknya undang-undang yang dibahas menjadi sepenuhnya berada di tangan DPR dan Presiden. Pernyataan yang terdengar melawan arus ini didasarkan pada premis bahwa konsep bikameral lahir justru untuk mendorong adanya checks and balances di dalam lembaga perwakilan. Kebutuhan terkait adanya dua dewan dalam satu lembaga perwakilan adalah untuk mewakili konstituensi yang berbeda sehingga terjadi proses deliberasi yang lebih baik. Karena itu pula, biasanya wewenangnya dibuat sedemikian rupa sehingga ada kelebihan dan kekurangan yang didesain berbeda di antara keduanya. Dengan begitu, dapat terjadi proses yang membatasi kewenangan yang berlebihan dari suatu lembaga politik.

Sistem ketatanegaraan apabila mengacu kepada esensi bikameral kuat dan efektif, maka peran yang ideal dari DPD setidaknya ada empat peran, yakni: Pertama, DPD harus semakin mempertegas posisinya sebagai 'penyambung lidah rakyat' di daerah. Harus digarisbawahi bahwa DPD sebagai perwakilan wilayah menjadi penting untuk ditegaskan bahwa keberadaan DPD tidak hanya sekadar membagi tugas antara dalam ataupun luar negeri, sebagaimana praktik parlemen di Amerika Serikat, melainkan juga memperjuangkan aspirasi daerah, khususnya yang terkait dengan kepentingan daerah di tingkat nasional. Kedua, DPD berperan sebagai lembaga penyeimbang dari DPR, agar fungsi check and balances di parlemen dapat berjalan. Sebagaimana diuraikan di atas, posisi DPR yang terlalu kuat dan dominan membangun hubungan antara DPR dan eksekutif. Di samping itu, dengan adanya check and balances, produk yang dihasilkan parlemen akan lebih komprehensif. Ketiga, peran DPD untuk membantu meringankan beban dan tugas yang diemban oleh DPR. Dengan berbagai produk yang harus dihasilkan, maka dibutuhkan lembaga mitra untuk membahas setiap RUU ataupun permasalahan yang berkaitan dengan tugas dan tanggung jawab dari parlemen. Keempat, DPD harus mengambil inisiatif dalam berbagai hal terkait dengan masalah kebangsaan, baik yang bersifat lokal maupun nasional. Hal ini harus melekat pada institusi DPD, sebagaimana juga melekat di DPR. Peran ini menjadi bagian dari pembuktian bahwa DPD adalah salah satu kamar yang berperan aktif 
dalam perpolitikan nasional. Bila keempat hal ini bisa dijalankan, maka problematika kewenangan DPD akan dapat diurai secara perlahan.

\subsection{Sistem Perwakilan dalam UUD NRI 1945}

Amandemen Undang-Undang Dasar 1945 telah membawa perubahan besar dalam kehidupan bangsa Indonesia. Perubahan ini terdapat dalam konsep perwakilan yang diterapkan dalam ketatanegaraan Indonesia. Dalam Pasal 22E ayat (3) dan (4) UUD NRI 1945 yang menyatakan bahwa:

(3) Peserta pemilihan umum untuk memilih anggota Dewan Perwakilan Rakyat dan anggota Dewan Perwakilan Rakyat Daerah adalah partai politik.

(4) Peserta pemilihan umum untuk memilih anggota Dewan Perwakilan Daerah adalah perseorangan.

Berdasarkan Pasal 22E ayat (3) dapat diartikan konsep perwakilan yang digunakan adalah perwakilan politik. Sedangkan, Pasal 22E ayat (4) dapat diartikan menggunakan konsep perwakilan teritorial/daerah karena yang dapat menjadi anggota DPD adalah perseorangan bukan dari unsur politik. Adanya perwakilan politik dan perwakilan daerah inilah yang sering dikatakan bahwa Indonesia menganut sistem bikameralisme.

Istilah struktur organisasi parlemen dua kamar atau dalam istilah lain disebut Bikameral. Dalam beberapa definisi tentang bikameralisme adalah sebagai berikut:

a. Bicameral sistem: A legislature which has two chamber rather then one (unicameral sistem), providing check and Balances and lessening, the risk of aletive dictatorship, at the birth of the united, Benjamin Franklin wrote that "a plural legislature is nesesary to good government as a single executive. Artinya: sistem bikameral adalah badan legislatif yang terdiri dari dua kamar untuk melaksanakan mekanisme check and balences agar terhindar dari resiko pemerintah yang diktator, Benjamin Franklin menulis kemajemukan pembuat undang-undang adalah cara unuk menjadikan pemerintah yang baik (good government) diatas eksekutif yang tunggal.

b. Bicameral: the division of legislative or judikal body into to components or cembers. The US congress is a bicameral legislature, sinse its dividedinto to houses, the senate and the house of representative. Artinya: bikameral adalah devisi dalam badan legislatif yang terdiri dari baberapa komponen atau kamar. Di Amerika kongres terdiri dari dua kamar yaitu senat dan house of representative.

c. Bicameral of legislature having two legislative House (usu. The house of refresentatives, or the assembly, and the sanate). The federal government and all states excep nabraska have bicameral legislatures. Artinya: sistem bikameral dalam badan pembuat undangundang terdiri dari dua badan atau kamar (biasanya disebut house of refresentatives dan senate), setiap pemerintahan yang menganut sistem federal mempunyai dua badan pembuat undang-undang.

Undang-undang Nomor 42 Tahun 2014 Tentang perubahan atas Undang-undang Nomor 17 Tahun 2014 Tentang MPR, DPR, DPD, dan DPRD memperlihatkan bahwa kewenangan legislasi DPD masih dibatasi pada: (1) kewenangan mengajukan rancangan undang-undang, (2) ikut membahas rancangan undang-undang, (3) 
menyusun dan menyampaikan daftar inventaris masalah, (4) melakukan pengawasan, (5) menyampaikan hasil pengawasan atas pelaksanaan undang-undang, dan (6) menyusun program legislasi nasional yang berkaitan dengan otonomi daerah, hubungan pusat dan daerah, pembentukan dan pemekaran serta penggabungan daerah, pengelolaan sumber daya alam dan sumber daya ekonomi lainnya, serta yang berkaitan dengan perimbangan keuangan pusat daerah. Dengan demikian, DPD tidak memiliki kewenangan membentuk undang-undang dalam bentuk penetapan/pengesahan rancangan undang-undang, meskipun rancangan undangundang yang berkaitan dengan otonomi daerah, hubungan pusat dan daerah, pembentukan dan pemekaran serta penggabungan daerah, pengelolaan sumber daya alam dan sumber daya ekonomi lainnya, serta yang berkaitan dengan perimbangan keuangan pusat dan daerah.

Undang-undang Nomor 42 Tahun 2014 tentang perubahan atas Undang-undang Nomor 17 Tahun 2014 tentang MPR, DPR, DPD, dan DPRD telah mereduksi kewenangan legislasi DPD. Pasal 162 ayat 1 menyebutkan bahwa: "DPR memegang kekuasaan membentuk undang-undang. Dengan ketentuan hal ini, maka RUU dari DPD yang jelas ditentukan dalam ketentuan Pasal 22D ayat (1) UU 1945. Kedudukannya direduksi menurut Pasal 162. UUD NRI 1945 Tahun 1945 telah mendudukkan RUU dari DPD seperti halnya RUU dari Presiden (Pasal 20 ayat (1) UUD NRI Tahun 1945). Ketentuan Pasal 162 jelas bertentangan dengan ketentuan Pasal 22D ayat (1), karena telah memperlakukan RUU yang diajukan DPD menjadi sama seperti usul RUU dari Anggota DPR atau alat kelengkapan DPR. Kondisi ini diakibatkan karena para penyusun UU Nomor 17 Tahun 2014 Tentang Susunan Kedudukan MPR, DPR, DPD dan DPRD mempresepsikan kedudukan RUU dari anggota DPR 9Pasal 21 UUD NRI Tahun 1945), sehingga secara kelembagaan, kedudukan DPD tidak setara dengan DPR. Hal ini tidak sesuai dengan jiwa dan semangat dari Perubahan UUD 1945 yang bermaksud untuk menciptakan proses checks and balances dalam pembentukan undang-undang dalam sistem ketatanegaraan Indonesia.

Undang-undang Nomor 42 Tahun 2014 tentang perubahan atas Undang-undang Nomor 17 Tahun 2014 tentang MPR, DPR, DPD dan DPRD secara sistematis tidak mengikutsertakan DPD dari awal proses pengajuan Rancangan Undang-Undang. Peniadaan kewenangan DPD dalam proses legislasi telah dimulai secara sistematis, sejak awal proses pengajuan RUU. Hal tersebut terlihat jelas di dalam Pasal 166 ayat (5): "DPR dan Presiden mulai membahas rancangan undang-undang dari DPD". Sebagaimana telah dikemukakan, melalui ketentuan Pasal 22D ayat (1) UUD 1945, DPD mempunyai wewenang untuk menyampaikan RUU bidang tertentu kepada DPR. Wewenang ini menunjukkan DPD sebagai representasi daerah dalam mempresentasikan kepentingan daerah dalam bidang legislasi sangat kuat, meskipun RUU dari DPD disampaikan kepada DPR.

Undang-undang Nomor 42 Tahun 2014 tentang perubahan atas Undang-undang Nomor 17 Tahun 2014 tentang MPR, DPR, DPD dan DPRD juga tidak diberi kesempatan memberikan pernyataan persetujuan atau penolakan. Dalam rangka pembahasan RUU, DPD diberikan peran sampai pada pembahasan tingkat pertama tetapi tidak turut serta dalam proses pengambilan keputusan. Makna "ikut membahas" sebagaimana ketentuan Pasal 22D ayat (2) UUD 1945 secara ekstensif adalah keterlibatan DPD dalam seluruh proses pembahasan sebuah RUU bidang 
tertentu, termasuk di dalamnya pemberian persetujuan. Selain hal tersebut, Undangundang Nomor 42 Tahun 2014 tentang perubahan atas Undang-undang Nomor 17 Tahun 2014 tentang MPR, DPR, MPR, dan DPRD masih mendudukkan DPD secara lemah dengan memberikan peran kepada DPD pada pembicaraan tingkat II, pengambilan keputusan dilakukan oleh DPR dan Pemerintah dalam rapat paripurna DPR dengan kegiatan:

a. Penyampaian laporan yang berisi proses, pendapat mini fraksi, pendapat mini DPD, dan hasil pembicaraan tingkat I

b. Pernyataan persetujuan atau penolakan dari tiap-tiap fraksi dan anggota DPR secara lisan yang diminta oleh pimpinan rapat paripurna

c. Sesuai dengan pasal 171 ayat 1-4 yaitu Pendapat akhir Presiden yang disampaikan oleh menteri yang ditugasi

Dibatasinya kewenangan legislasi DPD dalam Undang-undang Nomor 42 Tahun 2014 tentang Perubahan atas Undang-Undang Nomor 17 Tahun 2014 tentang MPR, DPR, DPD, dan DPRD mempertegas sejarah perdebatan dalam Amandemen 1945 dimana ide bikameralisme mendapat tantangan yang keras dari kelompok konservatif di Panitia Ad Hoc Perubahan UUD 1945 di MPR 1999-2002, sehingga yang disepakati adalah rumusan yang tidak dapat disebut menganut sistem bikameral sama sekali. Pada gilirannya, DPD tidak mempunyai kewenangan membentuk undang-undang sejajar dengan DPR. Oleh karena itu, kedudukannya hanya bersifat penunjang terhadap fungsi DPR di bidang legislasi sehingga DPD paling jauh hanya dapat disebut co-legislator yang sepenuhnya. ${ }^{16}$

Dari beberapa pengertian diatas dapat dipahami bahwa, lembaga perwakilan rakyat dua kamar pada dasarnya merupakan suatu bentuk wadah demokrasi perwakilan yang terdiri dari dua kamar atau dua dewan. Bentuk semacam ini merupakan proses panjang penyelenggaraan negara di berbagai belahan dunia, sejak awal timbulnya gagasan mengenai demokrasi perwakilan, muncul keinginan untuk menciptakan demokrasi yang bertugas untuk menghasilkan keputusan-keputusan penting dalam penyelenggaraan negara. Berdasarkan hal tersebut, sistem parlemen dua kamar (bicameral parliament) lebih dekat dengan sistem ketatanegaraan Indonesia. Hal ini dikarenakan Indonesia menganut dua dari tiga karakter perwakilan yaitu perwakilan politik (DPR) dan perwakilan teritorial/daerah (DPD). Namun terlepas dari itu semua, fungsi tugas dan kewenangan DPD ternyata sangat lemah, padahal dalam penggunaan sistem parlemen dua kamar keduanya harus memiliki kedudukan yang seimbang untuk tercapainya system checks and balance. ${ }^{17}$

DPD harus mempunyai peran fungsi dan kewenangan yang lebih kuat lembaga parlemen dalam memperjuangkan kepentingan masyarakat dan daerah serta dalam rangka penguatan demokrasi di Indonesia, Ini artinya diperlukan amandemen lagi terhadap UUD 1945. Hal ini dimungkinkan sebagaimana ketentuan pasal 37 ayat 1 UUD 1945. Usul ini dilandasi atas pertimbangan: Bahwa DPD memiliki legitimasi yang kuat karena dipilih secara langsung oleh rakyat, karena itu seharusnya memiliki kewenangan formal yang tinggi. Usul pemberian kewenangan yang memadai itu karena DPD sebagai lembaga negara kedudukannya sama dengan lembaga negara

\footnotetext{
16 Jimly Asshiddiqie, Perkembangan Dan Konsolidasi Lembaga Negara Pasca Reformasi, 2017.

17 Adnan Jamal, "Redesain Model Kameralisme Parlemen Dalam Sistem Ketatanegaraan Indonesia," Halu Oleo Law Review 1, no. 1 (2017): 23-42.
} 
lainnya. Dengan kewenangan yang sangat terbatas, mustahil bagi DPD untuk memenuhi harapan masyarakat dan daerah serta mewujudkan maksud dan tujuan pembentukan DPD. Penerapan prinsip check and balances antar lembaga legislatif harus diwujudkan.

Dalam rangka penguatan kapasitas DPD yang memadai dan lebih bagus, diperlukan adannya penyempurnaan tatanan negara yang lebih bisa menjamin kedaulatan rakyat dan prinsip cheks and balances antar lembaga negara. Dalam kekuasaan legislatif, perlu ditata kembali prinsip kesetaraan, saling mengontrol dan mengimbagi antara DPR dengan DPD. Tujuan ke arah tersebut akan berujung perlunya melakukan perubahan UUD 1945 secara komprehensif, dan dalam konteks DPD perlu penyempurnaan pasal $22 \mathrm{D}$.

Terlebih DPD telah memberikan penguatan kehidupan demokrasi, khususnya yang berkaitan dengan daerah dengan menyerap aspirasi dan kepentingan daerah, serta memperjuangkan kepentingan masyarakat dan daerah kepada Pemerintah atau di tingkat nasional. Hal ini niscaya juga akan mendekatkan pemerintah pusat dan pemerintah daerah, dan antara masyarakat dengan pemerintah. Pada kelanjutannya akan dapat memupuk dan memperkuat perasaan akan manfaat pemerintah serta memperkokoh persatuan dan kesatuan nasional. Bahwa DPD juga menunjukkan penguatan demokrasi dapat dilihat dari beberapa segi, antara lain: Sistem pemilihan anggota DPD dilakukan secara langsung oleh rakyat sebagai pemilik kedaulatan. Selain itu, DPD sebagai perwakilan daerah menunjukkan akomodasi dan representasi wilayah artinya ada penyebaran perwakilan dari seluruh wilayah/provinsi di Indonesia.

Penguatan DPD tak perlu lagi dikaitkan dengan bentuk federalisme dengan sistem perwakilan bikameral. Memang benar bahwa banyak negara yang menganut federalisme menggunakan sistem perwakilan bikameral, tetapi juga banyak negara yang berbentuk negara kesatuan menganut sistem perwakilan bikameral. Dalam konteks Indonesia, yang memiliki wilayah sangat luas, terdiri dari ribuan pulau dengan tingkat heteroginitas tinggi, penduduknya banyak, kiranya tidak salah jika Indonesia memilih sistem bikameral. Eksistensi DPD yang kuat ke depan harus dipertahankan, dan pilihan sistem perwakilan bikameral tidak perlu dikhawatirkan akan menuju federalisme. Tentu saja harus secara berlanjut dilakukan sosialisasi aturan sistem ketatanegaraan yang disepakati di samping juga menjaga dan memperkokoh jati diri bangsa, yaitu Pancasila, UUD 1945, Negara Kesatuan Republik Indonesia dan Bhineka Tunggal Ika.

\section{Kesimpulan}

Keberadaan lembaga perwakilan dalam sistem presidensial adalah sebagai perisai terwujudnya demokrasi yang sejuk, karena sebagai organ yang memiliki fungsi legislasi, Lembaga perwakilan juga menjadi pengawas eksekutif dalam menjalankan tugas dan kewenangannya. Dalam Praktiknya di Indonesia, keberadaan DPR dan DPD merupakan perwujudan lembaga perwakilan tersebut. Namun, yang menjadi persoalan adalah ketidak berimbangan kewenangan yang dimiliki anatara DPD dan DPR. Kewenangan DPD berkaitan dengan penyelenggaraan otonomi daerah yang sebatas memberikan pertimbangan pun menampakkan kelemahan fungsi DPD karena tidak dapat memperjuangkan kepentingan daerah terhadap kemungkinan pertimbangan usul, ataupun saran DPD yang tidak ditindaklanjuti oleh DPR. 
Kehadiran DPD yang anggotanya dipilih secara langsung oleh rakyat diharapkan dapat menjadi perwakilan masyarakat dan daerah yang dapat secara optimal mencerminkan kedaulatan rakyat dan efektif dapat menghubungkan antara daerah dengan pemerintah serta membawa kepentingan daerah pada tingkat nasional. Namun, DPD masih banyak mengalami kendala yang diakibatkan adanya keterbatasan fungsi dan kewenangan untuk mewujudkan harapan masyarakat dan daerah. Keterbatasan kewenangan DPD juga tidak sesuai semangat dan jiwa yang terkandung dalam maksud dan tujuan diadakannya DPD sebagai lembaga perwakilan daerah serta perwujudan prinsip check and balances. Berbagai upaya yang dilakukan, telah menunjukkan perkembangan dengan sinyal positif hubungan DPR dan DPD. Hubungan yang baik itu diharapkan akan wujud dalam kesederajatan dan kebersamaan DPR dan DPD dalam lembaga legislatif atas dasar prinsip check and balances dalam kerangka melaksanakan Pancasila, UUD 1945, koridor kokohnya NKRI yang berbhineka Tunggal Ika untuk mewujudkan kesejahteraan rakyat. Atas dasar hal tersebut di atas dan dengan niat yang kuat untuk mengembangkan demokrasi modern berdasarkan konstitusi dalam tata kenegaraan, maka eksistensi DPD RI harus dipertahankan dan diperkuat kapasitas kelembagaannya sebagai badan legislatif.

Melalui DPD ini diharapkan hubungan dengan otonomi daerah dan pusat dan daerah, pembentukan, dan pemekaran serta penggabungan daerah, pengelolaan sumber daya alam,dan sumber daya ekonomi lainnya,serta yang berkaitan dengan perimbangan keungan pusat dan daerah bisa berjalan dengan baik. Harus ada amandemen UUD 1945 terkait kewenangan legislasi DPD. Konkretnya bahwa DPD adalah lembaga legislatif, selayaknya memiliki kewenangan membuat undang-undang bersama DPR. Tanpa ada perubahan terhadap UUD 1945, maka sesanter apapun aspirasi masyarakat dan daerah yang dikawal anggota DPD, tetap tidak mudah untuk ditindaklanjuti dan direalisasi. Dengan kata lain, tanpa adanya amandemen UUD 1945 terkait kewengan DPD, diprediksi nasib masyarakat dan daerah tidak akan berubah signifikan ke arah yang lebih baik, lebih sejahtera, dan lebih menguatkan NKRI.

\section{Daftar Pustaka}

Adityanatha, I Gusti Ngurah. “Kajian Yuridis Hak Angket Dewan Perwakilan Rakyat Terhadap Komisi Pemberantasan Korupsi (Dikaji Dari Perspektif Hukum Tata Negara)." Acta Comitas: Jurnal Hukum Kenotariatan 4, no. 1 (2019): 142-53.

Arifin, Firmansyah. "Lembaga Negara Dan Sengketa Kewenangan Antarlembaga Negara." Jakarta: Konsorsium Reformasi Hukum Nasional, 2005.

Asshiddiqie, Jimly. "Pengantar Ilmu Hukum Tata Negara Jilid II," 2006.

- - - . Perkembangan Dan Konsolidasi Lembaga Negara Pasca Reformasi, 2017.

Atok, Rosyid Al. "CHECKS AND BALANCES DALAM PEMBENTUKAN UNDANGUNDANG DENGAN SISTEM BIKAMERAL DI 5 (LIMA) NEGARA KESATUAN." Jurnal Legislasi Indonesia 13, no. 3 (2018): 261-72.

Fauziyah, Fauziyah, and I Wayan Parsa. "The Concept of Special Judicial Institutions in Dispute Resolution of Village Heads In Indonesia." Jurnal Magister Hukum Udayana (Udayana Master Law Journal) 9, no. 4 (2020): 673-83.

Huda, Ni'matul. “Gagasan Amandemen (Ulang) UUD 1945 (Usulan Untuk Penguatan DPD Dan Kekuasaan Kehakiman)." Jurnal Hukum IUS QUIA IUSTUM 15, no. 3 (2008): 373-92.

Jamal, Adnan. "Redesain Model Kameralisme Parlemen Dalam Sistem Ketatanegaraan Indonesia." Halu Oleo Law Review 1, no. 1 (2017): 23-42. 
RI, Sekretariat Jenderal DPD. Profil Dewan Perwakilan Daerah Republik Indonesia Tahun Sidang 2014- 2015. Jakarta: Sekretariat Jenderal DPD RI, 2015.

Ridlwan, Zulkarnain, and Ade Arif Firmansyah. "Law Enforcement and Justice: Perspective of Authority and Responsibility of the President towards the Judicial System." Jurnal Magister Hukum Udayana (Udayana Master Law Journal) 9, no. 1 (2020): 1-14.

Siahaan, Pataniari. Politik Hukum Pembentukan Undang-Undang Pasca Amandemen UUD 1945. Konstitusi Press, 2012.

Sipangkar, Lenny M L, and Hak Asasi Manusia Sumatera Utara. "Penguatan Fungsi Legislasi Dewan Perwakilan Daerah (Strengthening The Legislative Function Of Regional Refresentative Council)." Dari Redaksi, 2018, 235.

Sonata, Depri Liber. "Metode Penelitian Hukum Normatif Dan Empiris: Karakteristik Khas Dari Metode Meneliti Hukum." Fiat Justisia Jurnal Ilmu Hukum 8, no. 1 (2014): 15-35.

Sunggono, Bambang. Metodologi Penelitian Hukum. PT. Rajagrafindo Persada, 2011.

Tutik, Titik Triwulan. "Harmonisasi Fungsi DPD Dan DPR Pada Lembaga Perwakilan Rakyat Dalam Sistem Bikameral Guna Pelaksanaan Checks and Balances." Yustisia Jurnal Hukum 1, no. 3 (2012).

Tutik, Titik Triwulan, and M H SH. Konstruksi Hukum Tata Negara Indonesia Pasca Amandemen UUD 1945. Prenada Media, 2016.

\section{Peraturan Perundang-Undangan}

Undang-Undang Dasar Negara Republik Indonesia Tahun 1945

Undang -undnag 23 tahun 2014 tentang pemerintahan daerah

Undang-Undang 42 tahun 2014 tentang Perubahan atas Undang-Undang Nomor 17 Tahun 2014 Tentang Majelis Permusyawaratan Rakyat, Dewan Perwakilan Rakyat, Dewan Perwakilan Daerah, dan Dewan Perwakilan Rakyat Daerah 